\title{
The effect of transcutaneous electrical nerve stimulation on the viability of random skin flaps in rats
}

\author{
Richard Eloin Liebano PT, Lydia Masako Ferreira MD, Miguel Sabino Neto MD
}

RE Liebano, LM Ferreira, MS Neto. The effect of transcutaneous electrical nerve stimulation on the viability of random skin flaps in rats. Can J Plast Surg 2002;10(4):151-154.

The aim of this study was to determine the role of transcutaneous electrical nerve stimulation (TENS) in the viability of random skin flaps. In 30 Wistar-EPM rats, a random $10 \times 4 \mathrm{~cm}$ skin flap was raised and a plastic barrier was interposed between the flap and its bed. Immediately after surgery and for two subsequent days, the rats in group 1 (the control group) were anesthetized for $1 \mathrm{~h}$ with the electrodes positioned in the base of the flap and without the administration of the electric stimulus. The rats in group 2 (the treatment group) were submitted to TENS for $1 \mathrm{~h}$ immediately after the surgery and for two subsequent days.

The percentage of necrotic area (averages of $43.11 \%$ in the rats in group 1 and $23.52 \%$ in the rats in group 2) was calculated on the seventh postoperative day in both groups.

Statistical analysis proved that TENS was more efficient in increasing random skin flap viability than was the method used in the control group.

Key Words: Electrical stimulation; Flaps; Rats; Viability

\section{Effet de la neurostimulation transcutanée sur la viabilité de lambeaux cutanés choisis au hasard chez des rats}

RÉSUMÉ : L'étude visait à déterminer le rôle de la neurostimulation transcutanée dans la viabilité de lambeaux cutanés choisis au hasard. Nous avons d'abord soulevé un lambeau cutané de $10 \mathrm{~cm}$ sur $4 \mathrm{~cm}$ chez 30 rats Wistar-EPM, puis inséré une pellicule de plastique entre le lambeau et son lit. Immédiatement après l'intervention et pendant les deux jours qui ont suivi, nous avons anesthésié les rats du groupe 1 (groupe témoin) pendant une heure et posé des électrodes à la base du lambeau sans toutefois procéder à l'électrostimulation, tandis que nous avons soumis les rats du groupe 2 (groupe expérimental) à la neurostimulation transcutanée pendant une heure.

Sept jours après l'intervention, nous avons calculé le pourcentage de zones nécrosées dans les deux groupes (moyennes de 43,11 \% chez les rats du groupe 1 et de $23,52 \%$ chez les rats du groupe 2 ).

D'après l'analyse statistique, la neurostimulation transcutanée s'est avérée plus efficace que la méthode utilisée dans le groupe témoin pour accroître la viabilité des lambeaux cutanés choisis au hasard.
Gin flaps are used largely in all fields of plastic surgery, Sespecially in reconstruction (1). The main and most feared complication for plastic surgeons in the creation of the flap is ischemia that develops to tissue necrosis in a large number of cases and causes a failure in the proposed treatment $(2,3)$. Due to that complication, a considerable amount of research has been done with the aim of improving the blood flow in flaps, decreasing ischemic conditions and preventing necrosis (3-9).
In the literature, there have been publications about several types of drugs, such as vasodilators, calcium channel blockers, prostaglandin inhibitors, anticoagulants, antiadrenergics and antioxidants (3,10-12). Unfortunately, many of those drugs present undesirable adverse effects, which makes their use in clinical practice unviable $(3,6)$. Therefore, a new research field using nonpharmacological agents such as acupuncture and electroacupuncture $(13,14)$, pulsed electromagnetic energy (15), low-power

Plastic Surgery Division, Surgery Department, Universidade Federal de São Paulo, Escola Paulista de Medicina, São Paulo, Brazil Correspondence and reprints: Dr Richard Eloin Liebano, Rua Macucos, 84, Jardim Analice, São José do Rio Preto, São Paulo, CEP 15070-270, Brazil. Telephone +55-17-224-3544, fax +55-11-557-16579, e-mail charde@riopreto.com.br 


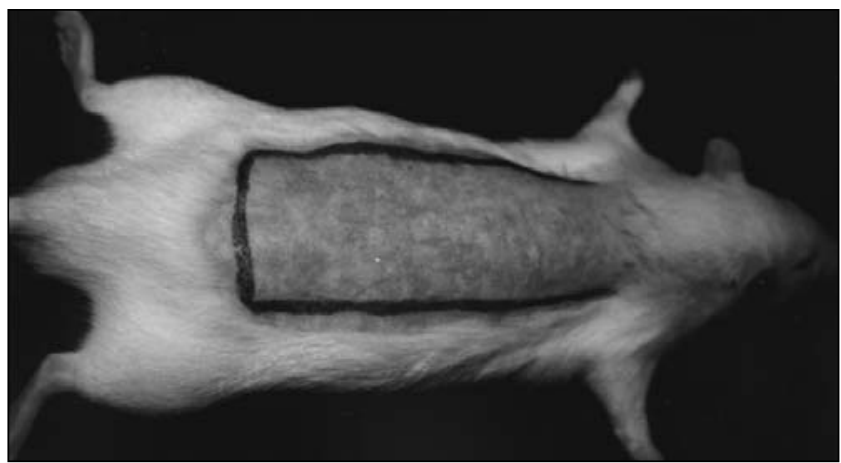

Figure 1) Planning flap in pattern sizes $(10 \times 4 \mathrm{~cm})$

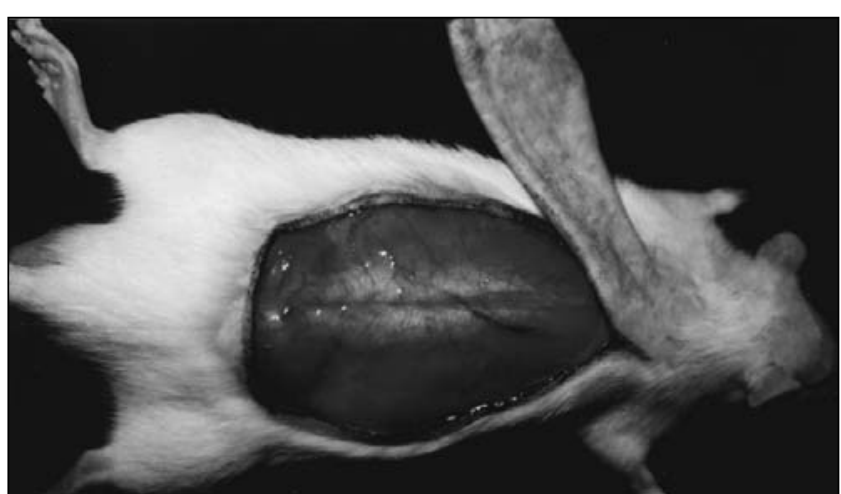

Figure 2) Random skin flap raised

lasers (16-18), monophasic electrical currents $(6,7,19)$ and biphasic electrical currents $(8,14,20)$ has emerged.

Transcutaneous electrical nerve stimulation (TENS) is a well defined method of pain management; however, some studies found an increase in skin temperature and perfusion in healthy subjects (21). This important discovery prompted research into the effects of TENS on chronic ulcers and flaps.

The present study was designed to assess the effect of TENS on the viability of random skin flaps in rats.

\section{MATERIALS AND METHODS}

Thirty Wistar EPM-1 adult male rats, weighing 260 to $330 \mathrm{~g}$, were randomly assigned to two groups. Rats in group 1 (the control group, $\mathrm{n}=15)$ received shaw stimulation, while those in group $2(n=15)$ were subjected to TENS.

All rats were anesthetized with sodium thiopental $(50 \mathrm{mg} / \mathrm{kg})$ intraperitoneally and were then depilated. A random skin flap measuring $10 \times 4 \mathrm{~cm}$ was elevated with a cranial base on the back of each rat $(11,22,23)$ (Figures $1,2)$. A plastic barrier with the same dimensions was placed between the flap and its bed $(10,11,23,24)$ (Figure 3) and was closed with simple nylon 4-0 stitches (Figure 4).

After surgery, the rats in group 1 were kept anesthetized for $1 \mathrm{~h}$, with the electrodes placed on the base of the flap, but without the output of electrical stimulus. This procedure was repeated for two subsequent days. Rats in group 2 were subjected to TENS with high intensity $( \pm 15 \mathrm{~mA})$ and high frequency $(80 \mathrm{~Hz})$ for $1 \mathrm{~h}$ immediately after surgery

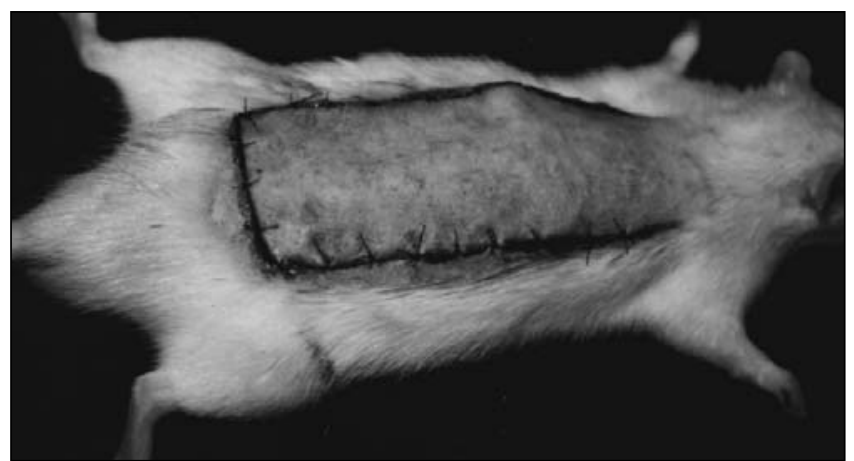

Figure 3) Suture with 4-0 nylon stitches after the flap was raised and a plastic barrier was interpositioned

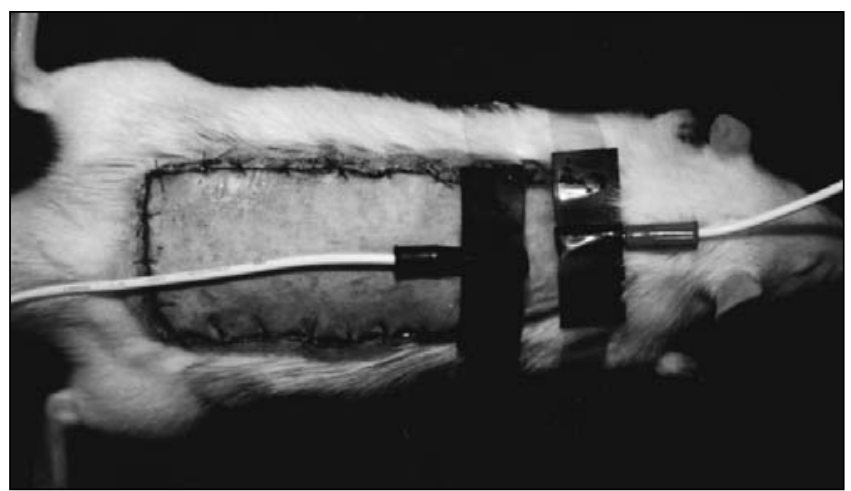

Figure 4) Electrodes were placed at the base of the flap for the transcutaneous electrical nerve stimulation

and for two subsequent days. The electrodes were placed on the base of the flap, which measured $4.2 \times 1.5 \mathrm{~cm}$. The pulses had a duration of $200 \mu s$.

On the seventh day after the operation, the distal necrotic area of the flap was checked via the paper template method (25).

\section{RESULTS}

The percentage of necrotic areas in the rats in group 1 ranged from $25.35 \%$ to $61.92 \%$ (average $43.11 \%$ ), while in the rats in group 2 it ranged from $7.03 \%$ to $39.92 \%$ (average $23.52 \%)$.

The Mann-Whitney test for independent groups showed that the differences between the two groups were statistically significant (Table 1).

\section{DISCUSSION}

The observation of the increase in blood flow as the result of TENS caused us and other authors to study its effect on the healing of chronic ulcers and on skin flap viability.

According to Kerrigan (2), the loss of a skin flap can be attributed to both extrinsic and intrinsic factors. Extrinsic factors include systemic (infection, arteriosclerosis, hypotension or malnutrition) and local (compression, tension or thrombosis of anastomosis) alterations, while inadequate blood flow is the only intrinsic factor.

Therefore, we agreed with Kerrigan (2) that treatment modalities that increase arterial inflow to the skin flap or 
stabilize cellular membranes in ischemic tissue should be chosen.

In our study, we used a model of skin flaps that develops ischemia in the distal portion, with measurements of $10 \times 4 \mathrm{~cm}(11,22,23)$. Plastic film was interposed between the flap and the bed to impede the revascularization of the flap through the bed vessels, thus guaranteeing homogeneous conditions of ischemia and necrosis $(10,11,23,24)$. The paper template method (25) was selected to evaluate the percentage of necrotic area, because it is simple and quick and requires only transparent paper and an accurate scale.

In the rats in group 1 , the average percentage of necrotic area was $43.11 \%$. In the rats in group 2, it was $23.52 \%$. The use of TENS was effective according to the model used, reducing the necrotic area of the distal portion of the flap in the rats in group 2 more than those in group 1. This result was in accordance with the findings of other studies $(6,7,14)$, although those studies involved different methods of surgical procedures and different types of electrical currents. The skin flap used in those studies $(6,7,14)$ was $7 \times 2$ $\mathrm{cm}$ and no barrier was positioned between the flap and the bed.

According to Alon (26), any electrical stimulation accomplished by surface electrodes attached to the surface of the skin represents a form of TENS, except in cases of denervation. Therefore, it is indispensable that we describe the type of electrical stimulation that was used in the present study. The current was pulsed and biphasic, with rectangular symmetrical pulses, and was, therefore, a nonpolarized current. Some authors $(6,7,19,27)$ used polarized currents in their studies. The disadvantages of this include the time limitation of application and care with intensity utilized. This may be very problematic, mainly due to the possibility of sensibility alterations in regions where the flap was accomplished (28), and therefore, it is possible for chemical burns of the skin to occur, harming the flap viability.

In our study, the pulse duration was fixed at $200 \mu$ s, as was the case with other researchers $(6,7,14)$. This pulse duration made it possible for the rats to provide a motor or sensory response, depending on the amplitude of the current.

An increase in blood flow has been demonstrated with motor and sensory stimulation. In the present study, we opted for the sensory stimulation because muscle contractions in the postoperative period can be painful and can cause some flap damage. The amplitude of the current was increased until we could see muscle contractions, and was then decreased by $1 \mathrm{~mA}$. Therefore, we were able to guarantee that the stimulation was being made at the sensory level. In the majority of the rats, the amplitude was close to $15 \mathrm{~mA}$. It did not seem correct to use a fixed amplitude because small variations in the positioning of the electrodes may have influenced the obtained responses.

Although we did not measure the blood flow in the skin, we believe that the increase in the survival of the flaps in the stimulated group was due to an increase in blood flow.

\begin{tabular}{lcc}
$\begin{array}{l}\text { TABLE 1 } \\
\text { Percentage of necrotic area on the seventh } \\
\text { postoperative day }\end{array}$ & \\
\hline Rat & Group 1 (\%) & Group 2 (\%) \\
\hline 1 & 41.97 & 22.26 \\
2 & 55.29 & 12.00 \\
3 & 37.04 & 28.52 \\
4 & 38.18 & 9.85 \\
5 & 39.43 & 13.12 \\
6 & 34.15 & 37.81 \\
7 & 45.60 & 22.13 \\
8 & 24.35 & 7.03 \\
9 & 38.85 & 32.18 \\
10 & 45.07 & 12.68 \\
11 & 41.48 & 38.22 \\
12 & 39.46 & 27.75 \\
13 & 51.06 & 22.00 \\
14 & 52.89 & 27.34 \\
15 & 61.92 & 39.92 \\
\hline Average & 43.11 & 23.52 \\
\hline
\end{tabular}

Mann-Whitney Test, Ucalculated=18.0 (statistically significant), $P<0.0001$

It is well known that TENS has the capacity to increase blood flow in the skin; however, the exact mechanism through which this happens is unknown. Two hypotheses to explain that discovery have been described in the literature. The first is that TENS, through the stimulation of the large-caliber mechanosensitive fibres, may cause an inhibition of the sympathetic vasoconstrictory neurons, resulting in a cutaneous vasodilation. Several authors have tried to demonstrate the effects of electrical stimulation on the sympathetic nervous system. Although some have alleged that there is an increase or no alteration of sympathetic responses $(29,30)$, the majority have found a sympathetic inhibition effect (31-33).

The other, and more accepted theory ivolves the liberation of some neuropeptides as the substance $\mathrm{P}$ and calcitonin gene-related peptide (CGRP), which are found in the terminations of afferent C-fibres. Those peptides can be released through the antidromic stimulation, also called the axon reflex. The stimulation occurs in the following order: sensory, motor and painful (26). Based on this principle, when a sensory stimulation occurs, there is no activation of 
nociceptive C-fibres. However, when a lesion occurs, just as with the surgical incision, the pain threshold can be reached immediately after the sensitive stimulation - that is to say, before the threshold motor (34).

Another possible explanation for the stimulation of this fibre type was the interaction with the beta-type A fibres through interneurons (35). That theory, however, was criticized by other researchers (36).

Aside from these peptides (substance $\mathrm{P}$ and CGRP), Kaada et al $(37,38)$ found a relationship between TENS

\section{REFERENCES}

1. Ferreira LM. Retalhos cutâneos. In: Ferreira LM, ed. Manual de Cirurgia Plástica. São Paulo: Atheneu, 1995:45-62.

2. Kerrigan CL. Skin flap failure: Pathophysiology. Plast Reconstr Surg 1983;72:766-77.

3. Davis ER, Wachholz JH, Jassir D, Perlyn CA, Agrama MH. Comparison of topical anti-ischemic agents in salvage of failing random-pattern skin flaps in rats. Arch Facial Plast Surg 1991;1:27-32.

4. Jurell G, Jonsson CE. Increased survival of experimental skin flaps in rats following treatment with antiadrenergic drugs. J Plast Reconstr Surg 1976;10:169-72.

5. Kjartansson J, Lundeberg T, Körlof B. Transcutaneous electrical nerve stimulation (TENS) in ischemic tissue. Plast Reconstr Surg $1988 ; 81: 813-5$

6. Kjartansson J, Lundeberg T, Samuelson UE, Dalsgaard J. Transcutaneous electrical nerve stimulation (TENS) increases survival of ischemic musculocutaneous flaps. Acta Physiol Scand 1988;134:95-9.

7. Kjartansson J, Lundeberg T, Samuelson UE, Dalsgaard J, Hedén P. Calcitonin gene-related peptide (CGRP) and transcutaneous electrical nerve stimulation (TENS) increase cutaneous blood flow in a musculocutaneous flap in the rat. Acta Physiol Scand 1988;134:89-94

8. Lundeberg T, Kjartansson J. Effect of electrical nerve stimulation on healing of ischemic skin flaps. Lancet 1988;24:712-4.

9. Gherardini G, Lundeberg T, Cui J, Eriksson SV, Trubek S, Linderoth B. Spinal cord stimulation improves survival in ischemic skin flaps: An experimental study of the possible mediation by calcitonin gene-related peptide. Plast Reconstr Surg 1999;103:1221-8.

10. Ugland O. Flaps and flap necrosis. Acta Chir Scand 1966;131:408-12.

11. Duarte IS, Gomes HF, Ferreira LM. Effect of dimethyl sulphoxide on necrosis of skin flaps in rats. Can J Plast Surg 1998;6:93-7.

12. ABLA, LEF. Efeito da N-Acetil-L-Cisteína sobre a necrose dos retalhos cutâneos, em ratos. São Paulo: Tese Mestrado Escola Paulista de Medicina, 1997.

13. Jansen G, Lundeberg T, Samuelson UE, Thomas M. Increased survival of ischemic musculocutaneous flaps in rats after acupuncture. Acta Physiol Scand 1989;135:555-8.

14. NiinaY, Ikeda K, Iwa M, Sakita M. Effects of electroacupuncture and transcutaneous electrical nerve stimulation on survival of musculocutaneous flap in rats. Am J Chin Med 1997;25:273-80.

15. Krag C, Taudorf U, Siim E, Bolund S. The effect of pulsed eletromagnetic energy (Diapulse) on the survival of experimental skin flaps. Scand J Plast Reconstr Surg 1979;13:377-80.

16. Kami T, Yoshimura Y, Nakajima T, Ohshiro T, Fujino T. Effects of low-power diode lasers on flap survival. Ann Plast Surg 1985;14:278-83.

17. Smith RJ, Birndorf M, Gluck G, Hammond D, Moore WD. The effect of low-energy laser on skin-flap survival in the rat and porcine animal models. Plast Reconstr Surg 1992;89:306-10.

18. Amir A, Solomon AS, Giler S, Cordoba M, Hauben DJ. The influence of helium-neon laser irradiation on the viability of skin flaps in the rat. Br J Plast Surg 2000;53:58-62.

19. Im JM, Lee WPA, Hoopes JE. Effect of electrical stimulation on survival of skin flaps in pigs. Phys Ther 1990;70:37-40. and the release of vasoactive intestinal polypeptide. According to the Kaada et al $(37,38)$, there may be a relationship between the liberation of this peptide and the cutaneous vasodilation.

New horizons are envisioned to enlarge the knowledge of the physical agents that are used with the purpose of minimizing the complications of surgical flaps. New experiments with different types of electrical currents and other physical agents can be performed so that we can better understand this unexplored field.
20. Kjartansson J, Lundeberg T. Effects of electrical nerve stimulation (ENS) in ischemic tissue. Scand J Plast Reconstr Hand Surg 1990;24:129-34.

21. Scudds RJ, Helewa A, Scudds RA. The effects of transcutaneous electrical nerve stimulation on skin temperature in assintomatic subjects. Phys Ther 1995; 75:622-8.

22. McFarlane RM, DeYoung G, Henry RA. The design of a pedicle flap in the rat to study necrosis and its prevention. Plast Reconstr Surg 1965;35:177-82.

23. Gomes HFC, Bueno PCS, Scardoeli CAC, Ferreira LM. Effect of nicotine in randomized skin flaps in rats. Rev Hosp S Paulo Esc Paul Med 1994;5:13-7.

24. Kaufman T, Angel MF, Eichenlaub EH, Levin M, Hurwitz DJ, Futrell J. The salutary effects of the bed on the survival of experimental flaps. Ann Plast Surg 1985;14:64-73.

25. Sasaki GH, Pang CY. Hemodynamics and viability of acute neurovascular island skin flap in rats. Plast Reconstr Surg $1980 ; 65: 152-8$

26. Alon G. Principles of electrical stimulation. In: Nelson RG Currier DP, eds. Clinical Electrotherapy, 2nd edn. Connecticut: Appleton \& Lange, 1991:35-103.

27. Reinish JF, Myers MB. Survival of experimental flaps pretreated with low-intensity direct current electrical delay. Surg Forum $1974 ; 25: 522-3$

28. Benediktsson KP, Perbeck L, Geigant E, Solders G. Touch sensibility in the breast after subcutaneous mastectomy and immediate reconstruction with a prosthesis. Br J Plast Surg 1997;50:443-9.

29. Ebersold ML, Laws ER, Albers JW. Measurements of autonomic function before, during and after transcutaneous stimulation in patients with chronic pain and in control subjects. Mayo Clin Proc 1977;52:228-32.

30. Wong RA, Jette PV. Changes in sympathetic tone associated with different forms of transcutaneous electrical nerve stimulation in healthy subject. Phys Ther 1984;64:478-82.

31. Owens S, Atkinson ER, Lees DE. Thermographic evidence of reduced sympathetic tone with transcutaneous nerve stimulation. Anesthesiology 1979;50:62-5.

32. Abram ES, Asiddao CB, Reynolds AC. Increased skin temperature during transcutaneous electrical stimulation. Anesth Analg $1980 ; 59: 22-5$

33. Linderoth B, Gunasekera L, Meyerson BA. Effects of sympathectomy on skin and muscle microcirculation during dorsal column stimulation: Animal studies. Neurosurgery 1991;29:874-9.

34. Verhoeven ARS. Diadinamics. Delft: BV Enraf-Nonius, 1985.

35. Cervero F, Laird JMA. Mechanisms of touch-evoked pain (allodynia): A new model. Pain 1996;68:13-23.

36. Wasner G, Baron R, Jänig W. Dynamic mechanical allodynia in humans is not mediated by a central presynaptic interaction of $\mathrm{Ab}$ mechanoreceptive and nociceptive C-afferents. Pain 1999;79:113-9.

37. Kaada B. Vasodilation induced by transcutaneous nerve stimulation in peripheral ischemia (Raynauld's phenomenon and diabetic polyneuropathy). Eur Heart J 1984;3:303-14.

38. Kaada B, Olsen E, Eielsen O. In search of mediators of skin vasodilatation induced by transcutaneous nerve stimulation: III. Increase in plasma VIP in normal subjects and in Raynaud's disease. Gen Pharmac 1984;15:107-13. 